\title{
REZILIENCIA A PEDAGÓGIÁBAN - A KOCKÁZAT ELLENSÚLYOZÁSA PEDAGÓGIAI ESZKÖZÖKKEL
}

\author{
ERDEI RóBERT \\ a B.A.Z. Megyei Pedagógiai Szakszolgálat Encsi Tagintézményének \\ igazgatója \\ erdeirobert@gmail.com
}

Az iskola megkezdésének időszaka különbözö mértékü kihivást, illetve nehézséget jelenthet a gyermekek számára. A tanulmány a reziliencia jelenségét, mint a fejlódést támogató lehetöséget mutatja be, amely új utakat nyithat meg a gyermekkori fejlödés optimális menetének fenntartásában. Bemutatásra kerülnek a reziliencia különbözö definíciói és legfontosabb pedagógiai vonatkozásai, amelyek a pedagógiai gyakorlat és a pedagógusképzés szempontjából is fontosak lehetnek. A szerzö - pedagógiai szempontokat is érvényesitve áttekinti a fejlödést veszélyeztetö legjellemzöbb és legnagyobb hatású rizikótényezöket is.

A gyermekkor egyik legfontosabb állomása az iskola megkezdésének időszaka. Az általános iskolai tanulmányaikat megkezdő gyermekek fejlettségi szintje nagyon eltérő lehet és abban is különböznek, hogy milyen mértékü „érettséggel” vagy „,felkészültséggel" bírnak az előttük álló átmenet sikeres teljesítésére. Sok gyermeket megvisel a változás és az új közeg, amibe be kell illeszkedniük, és eredményesen kell teljesíteniük. Mások ezzel szemben kifejezetten pozitívan veszik az akadályokat, sok esetben akár a környezetük által elvárt szintet meghaladóan teljesítve az akadályokat. A megfelelő alkalmazkodás és jó teljesítmény azonban az esetek jelentős részében nem kizárólag a tanuló személyiségén vagy képességein múlik, hanem az intézmények sajátosságai és gyakorlatai is nagyban hozzájárulhatnak a problémamentes iskolakezdéshez. A magyarországi pedagógiai gyakorlatba még nem igazán beépült tanulói, illetve gyermeki személyiségben megnyilvánuló reziliencia jelenségét és fogalmát vezeti be jelen tanulmány az iskolakezdés időszakára vonatkoztatva, amely az esetek jelentős százalékában magyarázatul szolgál a kezdeti időszak nehézségeivel, valamint az iskola megkezdésével kapcsolatos problémákkal való megküzdésre.

\section{A reziliencia definíciója}

Békés Vera (Békés, 2002) általános definíciója szerint a reziliencia rugalmas ellenálló képességet jelent, valamely rendszer azon képességére utal, hogy eröteljes, megújuló, illetve bizonyos esetekben sokkszerü külső hatásokhoz alkalmazkodjék. 
A reziliencia a hasonló fogalmakkal szemben rugalmas, képlékeny megmaradást jelent. Nem rendelkezik az ellenállás rigiditásával, a képlékenység tetszőlegesen alakítható értelmével, az inercia fogalmában rejlő lomhasággal, illetve a stabilitás értelmezésével sem, hanem mindezen fogalmakkal ellentétes.

Masten és Powell (2003) fejlődéslélektani szempontból a reziliencia meghatározására két alapvető feltétel teljesülését tartják szükségesnek, az egyén megfelelő elboldogulását az életében és nagymértékü rizikónak vagy nehézségeknek kitettségét jelenlegi helyzetében vagy korábbi időszakban. Masten (2001) kiemeli, hogy a reziliencia minősítése nem szolgál a személy teljes körü leírására, illetve nem alkalmas arra, hogy a személy életének minden szakaszát jellemezze. Egy adott pillanatban vagy fejlődési fázisban jól funkcionáló egyén nem fog szükségszerủen jól teljesíteni élete egy másik pillanatában vagy fejlődési szakaszában. Fontos továbbá, hogy Masten (2001) nem kizárólagosan a reziliens csoportot határozza meg. Ha a nagyfokú kockázatok rossz kimenetelekkel járnak együtt, az egyént sérülékenynek, rosszul alkalmazkodónak (maladaptívnak) jellemezhetjük, viselkedését pedig problémafókuszúan vagy akár pszichopatológiailag írhatjuk le. Ha a jó müködés mellett csekély vagy semmilyen rizikó nem áll fenn, akkor az egyént kompetensként, sikeresként, mentálisan egészségesként jellemezhetjük. Gyakorlati, és különösképpen pedagógiai szempontból fontos Masten (2001) elképzelése, aki a reziliencia jelenségét, az adaptív viselkedés megjelenését nem kivételesnek, hanem inkább általánosnak tekinti. Véleménye szerint az eddigieknél pozitívabban tekinthetünk az emberi fejlődésre és alkalmazkodási folyamatra. A rezilienciát, a sikeres alkalmazkodást és beilleszkedést, illetve a jó szintủ múködést és elboldogulást egyfajta hétköznapi mágiának tekinti, amely elérhető célként jelenik meg az esetek többségében.

Benard (2006), mint a pozitív pszichológia képviselője, a rezilienciát az egészséges emberi fejlődés folyamataként szemléli. A gondoskodó környezet, amely biztosítja az alapvető szükségleteket, képes arra, hogy az egyének saját, belső, rezilienciára való képességét hozzáférhetővé tegye. A belső jóllét elérésével lehetőség nyílik Norman Garmezy kifejezésével élve „védőpajzsot” nyújtani a fiataloknak, gondoskodó kapcsolatokat, magas elvárásokat és a részvétel lehetőségét biztosítva. A reziliencia belülről kifelé terjedő folyamat, amely akár teljes családok, osztályok, iskolák, közösségek sorsát képes átalakítani (Benard, 2006), hiszen az erre való képesség és a sikeres alkalmazkodás és hatékony müködés képessége nem csak egyéneket, hanem csoportokat is jellemezhet.

Ungar, Liebenberg, Boothroyd, Kwong, Lee, Leblanc, Duque, és Maknach (2008) egy újfajta értelmezést kínálnak, mely szerint a reziliencia az egyének képessége, hogy megtalálják az egészség javításához vezető utat, valamint az egyén fizikai és szociális környezetének képessége, hogy a megfelelő erőforrásokat biztosít számukra. Két folyamat irányítja a rezilienciát, a navigálás és az alkudozás vagy tárgyalás. Az egyénnek bizonyítania kell személyes képességeit azáltal, hogy az erőforrások között megfelelően navigál, például pozitív kötődéseket alakít ki, önér- 
tékelését fokozó tevékenységeket végez, oktatásban vesz részt, tagja a családnak és a tágabb közösségnek. Azonban a családnak és a közösségnek is elérhetőnek kell lenniük, amikor erőforrások megtalálására van szükség. Tárgyalásra, alkura van szükség ahhoz, hogy a biztosított erőforrások jelentőséggel bírjanak a segítséget kérő számára.

Bizonyos kutatók a rezilienciát egyensúlynak tekintik a stressz és a nehézségek, valamint a megküzdés képességei és a külső támogatás között. Ha a stresszt okozó jelenségek és hatások, azaz a stresszorok túlsúlyba kerülnek a védő faktorokkal szemben az egyén életében, az még a reziliens személyt is legyürhetik (Laursen és Birmingham, 2003).

A reziliencia komplex, számos összetevövel biró jelenség. A kompetencia megléte, a reziliencia különböző megnyilvánulási formái és a különböző tényezők figyelembevételének szükségessége lehetővé teszi különböző kimenetek létrejöttét. A kompetens müködés és a reziliencia közé nem lehet automatikusan egyenlöségjelet tenni, ahogyan arra már Masten (2001) is utalt, hiszen a kompetens müködés rizikó nélkül is lehetséges. Fontos tudni, hogy a reziliencia ugyan általánosan és rendszeresen megfigyelhető a különbözö kontextusokban, de pusztán az egyik lehetséges utat jelenti a fejlődés során.

\section{A reziliencia jelenségének pedagógiai vonatkozásai}

A reziliencia számos szempontból fontos, lényeges téma a pedagógia számára. A tanulmányban megjelenő szerteágazó témákat a gyakorlati pedagógia szempontjából tekintettem át.

Seiler (2008) véleménye szerint a reziliencia és a különféle kognitív képességek elsajátítása ahhoz is hozzásegítheti a gyerekeket, hogy a mindennapok során jelentkező nehézségekkel megküzdjenek, így az őket érő kritikával, csalódásokkal vagy például a bullyinggal.

Ceglédi (2012) is kiemeli a reziliencia komplex jellegét. Egyetlen területen tapasztalt pozitív megküzdés nem jelenti azt, hogy az egyén más területen is sikeresen boldogul. Ceglédi (2012) szerint az iskola egy olyan hely, ahol védő- és rizikófaktorok is jelen vannak, de ez szerencsés abból a szempontból, hogy a negatív események felügyelet mellett történhetnek. Az iskola egyfajta „védőoltásként” müködhet a sikeres alkalmazkodás kialakításában. A kockázatos tényezők megelőzését általában célravezetőbb megoldásnak gondolják, de azt is fontos látni, hogy bizonyos mértékü kihívással vagy nehézséggel mindenkinek szembe kell néznie. Ezt a szembenézést célszerübb egy támogató közegben megélni, hiszen ez lehetővé teszi, hogy a gyermekek ne görgessék maguk előtt a problémákat. Masten és Obradovic (2007) szerint a legkedvezőbb, ha a gyermek belülről fakadóan képes a környezet külső erőforrásait mozgósítani. 
Hodge (2009) megítélése szerint az Egyesült Államokban az 1960-as évektől kezdődően az oktatás minőségének javítására előirányzott programok, reformok, paradigmák részben ahhoz is vezettek, hogy sok tanuló éppúgy küzd az iskolai sikertelenséggel, mint korábban. E téren a magyar helyzet hasonló. Az Egyesült Államokban az elméleti és gyakorlati szakemberek érzékenyen reagáltak a problémákra, a rossz alkalmazkodásra az elmélet, a kutatás és a gyakorlat szintjén egyaránt, és olyan intézkedéseket, programokat szorgalmaztak, amelyek a megelözésre fókuszálnak. Hodge (2009) szerint ez a problémára irányuló túlzott figyelem ahhoz vezetett az oktatásban, hogy számos tanuló „rizikós”, „problémás” címkét kapott, amitől nem tudtak megszabadulni. Például a tanulási zavarral küzdő tanulók körében felerősödhetnek különféle negatív hatások, ti. e „besorolás” kapcsán a pedagógusok a tanulók korlátaira koncentrálnak, sokkal kevésbé a bennük rejlö lehetőségekre. Több kutató, így például Benard (2006) egyetért abban, hogy a rizikófaktorok feltárása helyes lépés annak érdekében, hogy javítsuk a tanulók életét, a gyakorlati szakembereknek ezt az információt azonban olyan programok kidolgozására kell felhasználniuk, amelyek alkalmasak arra, hogy a jelen levő rizikófaktorok hatását csökkentsék vagy megszüntessék.

A tanulók iskolai sikeressége vagy kudarca számos tényező függvénye, az azonban világos, hogy az intézmények gyakorlata és az iskolák általános tanulási környezete befolyásolja ezt. Padron, Waxman és Huang (1999) kutatása a reziliens és nem reziliens tanulók iskolai környezetben nyújtott teljesítményére és viselkedésére nézve érdekes eredményeket hozott. A reziliens tanulók a megfigyelt idő 85, míg a nem reziliensek 61 százalékában foglalkoztak a rájuk bízott feladattal, a reziliens tanulók szignifikánsan több időt töltöttek a tanárral folytatott interakcióval, valamint az iskola tanulási környezetét is pozitívabbnak találták. A kutatásnak bizonyos korlátai is voltak, ti. a tanulók reziliens vagy nem reziliens voltát a tanárok döntötték el. A reziliencia elmélete oktatási kontextusba helyezve azt az álláspontot képviseli, hogy a tanulókat saját jogukon kell elismerni és erre építeni, elkerülve azt, hogy a rezilienssé vagy nem rezilienssé minősítés egyszerü önbeteljesítő jóslattá váljon.

A reziliencia fejlesztését meghatározhatjuk elérendő pedagógiai célkitüzésként, azonban Blaustein és Kinniburgh (2010) álláspontja szerint ironikus azt feltételezni, hogy a gyerekek képesek a legnagyobb mértékü rezilienciára, mivel a traumatikus események hatása épp csecsemö- és gyermekkorban a legdrámaibb. Fontos cél azonban, hogy a puszta túlélést meghaladóan a gyermekek képesek legyenek a világhoz való megfelelő alkalmazkodásra a veszélyek és nehézségek kontextusán túl is. A gyermekekkel való foglalkozásnak ki kell terjednie azokra a tényezőkre is, amelyek az egészséges fejlődést és a kompetens alkalmazkodást biztosítják (Blaustein és Kinniburgh, 2010).

Az intézményes nevelés színterei, így az óvoda és iskola megjelenhet a gyermek életében akár rizikóként, akár védőfaktorként. Bizonyos esetekben jelenthet 
kifejezett veszélyt, máskor éppen az ellenkezőjét, sokszor akár az egyetlen olyan pontot a gyermek életében, ami egyfajta struktúrával és kiszámíthatóan müködő rendszerrel bír. Kiemelt jelentőségü a védőfaktorokat illetően a valahová tartozás érzése. Egy jó óvodai vagy iskolai közeg képes ezt nyújtani a tanulóknak, akik annál könnyebben képesek identifikálódni egy közösséggel, intézménnyel, minél inkább képes az biztonságot jelentő és befogadó-elfogadó tényezőként megjelenni. Az óvodai és iskolai kontextuson túlmenően a pedagógiai szakszolgálat intézményei is említést érdemelnek. A pedagógiai szakszolgálati intézmények komplex szolgáltatást nyújtanak olyan régiókban, illetve településeken is, ahol korábban szinte elképzelhetetlen volt a gyermekek számára olyan speciális végzettségü szakemberekhez eljutni, akik ma a pedagógiai szakszolgálatokban tevékenykednek (Blaustein és Kinniburgh, 2010; Alvord, Gurwitch és Palomares, 2003; Szakács, 2007).

A rizikó- és védőfaktorok felsorolásánál azért fontos a tényezők minden csoportját végiggondolni, mert nem kizárólag az iskolai oktatásból vagy óvodai nevelésből fakadó kockázatok és védelem érvényesül önmagában, hanem mindezek a hatások más tényezőkkel interakcióban jelennek meg. Így például az egyén jellemzői, a családi körülmények és a társadalom elvárásai, valamint az általa nyújtott támogatások is hatással vannak a pedagógiai munkára. Ilyen tényező a gyermek és a szomszédság kapcsolata is. Shumov, Vandell és Posner kutatásában (1999) azt találta, hogy a szomszédság jóval kevésbé jelenik meg védőfaktorként a gyermek életében, mint amennyire rizikót jelenthet. A tanulmány sürgeti az iskola utáni programok és közösségi szolgáltatások minél nagyobb mértékét, különösen azoknak, akik kockázatos környéken laknak. Mykota és Muhajarine (2005) azt találták, hogy a szomszédság, mint közösség mediálja a pozitív és negatív kimeneteket gyermekeknél.

Masten és Powell (2003) szerint az általános iskolás korosztály kompetenciája (ami a reziliencia fontos elemének is tekinthetö) a tanulmányi eredményekben, a megfelelő szintü kortárs kapcsolatokban és a kellően szocializált viselkedésben érhető tetten. Cox (2004) idézi a Garmezy által meghatározott faktorokat a gyermeki reziliencia vonatkozásában. E szerint a támogató személy a gyerek életében, támogató, erős kohéziójú család, bizonyos személyiségjellemzők azok a faktorok, amelyek lehetővé teszik a nehézségekkel való megküzdést.

Goldstein és Brooks (2013) úgy vélik, hogy az iskola, illetve az iskolába viszszatérés traumatikus események után fontos szerepet játszik a gyerekek életében. Az iskolában (optimális esetben) kialakuló kapcsolatok azok, amelyek leginkább képesek a gyerekek pszichés sebeinek gyógyítására. Az iskolák képesek arra is, hogy az arra rászoruló gyerekeknek egyénre szabott segítséget nyújtsanak, mint például fejlesztő foglalkozások, korrepetálás vagy tanórán kívüli foglalkozások, a gyermek pszichológiai, tanulmányi és társas jóllétének támogatására.

Merrell, Levitt és Gueldner (ismerteti: Peacock, Ervin, Daly és Merrell, 2010) három támogatási szintet különböztetnek meg az oktatási intézmények vonatkozásában. Az általános vagy elsödleges szint az adott iskola összes gyerekére irányul. 
Ennek fố célja a reziliencia és a mentális egészség fejlesztése iskolai és osztályszinten. Ezáltal a tanulók kevésbé lesznek rizikónak kitéve a tanulási és\vagy társas-viselkedési problémák tekintetében. Ezek a proaktiv jellegü stratégiák lehetővé teszik az iskoláknak erőforrásaik maximalizálását azáltal, hogy csökkentik azon tanulók számát, akik intenzív társas vagy viselkedési támogatásra szorulnak. Az iskolaszintü prevenció nemcsak a gyerekek szociális készségeit erösíti, csökkentve a problémás viselkedések megjelenését, hanem az iskola klímáját is javítja. A másodlagos stratégiák azért szükségesek, mert bizonyos tanulók nem reagálnak az általános, elsődleges megközelítésben alkalmazott stratégiákra. Így nekik intenzívebb, másodlagos megközelítésre van szükségük a problémák tovább súlyosbodásának elkerülésére. A másodlagos stratégiák azokat a gyerekeket célozzák meg, akiknél fennáll a krónikus érzelmi vagy viselkedési zavarok kockázata vagy a rossz beilleszkedés korai jeleit mutatják. Ezeknek a gyerekeknek általában nem egyénre szabott intenzív ellátás szükséges, hanem olyan intervenciós stratégiák, amelyek a rizikófaktoraikra koncentrálnak. Bizonyos gyerekeknél azonban szükséges a személyre szabott és gyakran hosszú ideig tartó odafigyelés súlyos mentális egészségbeli és társasviselkedési problémáik miatt. Profitálhatnak ugyan az elsődleges és másodlagos stratégiákból is, de leggyakrabban ezeken túlmutató segítséget igényelnek. Definíciószerüen a harmadlagos szint olyan egyén ellátását jelenti, aki jól meghatározott problémával vagy deficittel bír. A cél visszaállítani a személy lehető legmagasabb szintủ müködését, valamint elérni a fennálló zavar hatásainak minimalizálását és a komplikációk elkerülését. Kérdés azonban, hogy ennek a szintnek a kezelése az iskola feladata-e. Sok gyerek - a kérdésben rejlő kétely ellenére - vagy az iskolában részesül egyéni megsegítésben vagy sehol, véli Merrell, Levitt és Gueldner (ismerteti: Peacock és mtsai, 2010).

Fallon (2010) hangsúlyozza, hogy az iskolák szerepének megértése kiemelt jelentőségü a reziliencia, az adaptív válaszok, a sikeres beilleszkedés és a hatékony müködés fejlesztésében. Véleménye szerint az iskolák, amelyek képesek hatékonyan közremüködni a reziliencia fejlesztésében, a következő jellemzőkkel bírnak: erős vezetés, magas elvárások a tanulók felé, hangsúly az alapvető készségeken, hangsúly a rendezett környezeten, a tanulók rendszeres és alapos értékelése (Fallon, 2010).

Stoiber és Gettinger (2011) azt tapasztalták, hogy a reziliencia fejlesztését elvárni a tanároktól jóval kevésbé lehet hatékony felkészítés nélkül, mint megfelelö tréning után. A pozitív viselkedések támogatásának fejlesztése után nem csak a tanárok kompetenciája növekedett, hanem ennek következményeként a problémás viselkedésü gyermekek körében tapasztalható reziliencia mértéke is, amely együtt járt a viselkedési problémáik csökkenésével. A tanárok reziliencia fejlesztéséhez szükséges képességei megszerezhetőek specifikusan erre felkészítő tréningeken, de a pedagógusok képzésének részéve is tehető az ilyen irányú ismeretek és készségek oktatása és fejlesztése. A reziliencia jelenségkörének megértése, a mindennapi pedagógiai gyakorlatba történő beépítése a pedagógusok számára is hasznos, hiszen 
azon túlmenően, hogy sikeresen képesek lehetnek segítséget és támogatást, illetve erőforrásokat nyújtani a rizikónak kitett gyermekeknek, maguk a pedagógusok is képessé válnak a stresszel és a kiégés veszélyével való sikeresebb megküzdésre (Howard és Johnson, 2004).

Ha az iskolákban szükséges erőforrásokat mérlegeljük, akkor a költségek sokszor nem megkerülhetö tényezőt jelentenek. A mentorok, a fontos és biztonságot jelentő kapcsolatot nyújtó felnőttek hatékony védőfaktort, egyúttal költséghatékony megoldást is jelentenek (Werner, 2000).

Alvord és munkatársai (2003) szerint a reziliencia megléte nem jelenti azt, hogy a gyerek nem fog nehézségeket vagy stresszt megélni. A fájdalom és szomorúság általános jellemzője a reziliens személyeknek, például ha nagyobb traumát élnek át vagy személyes veszteséget szenvednek el, de akár olyan esetekben is, ha másokról hallja ezt. Ugyanakkor azt is kiemelik, hogy a rezilienciát meg lehet tanulni. A reziliencia felépítése és fejlesztése segíthet a gyerekeknek a stresszt és a bizonytalanság, a szorongás tüneteit kezelni. A reziliens müködések elsajátítására az iskola, illetve a nevelés-oktatás intézményei biztonságos terepet jelentenek.

A reziliencia kutatások megerősítik azt a vélekedést, hogy az otthon, az iskola és a környezet bizonyos jellemzői hatással vannak a gyermekek rezilienciájára. A pozitív és negatív viselkedések megjelenése annak az eredménye, hogy miként dolgozza fel a gyermek a rá ható rizikó- és védőfaktorokat. A családban, az iskolában és a közösségben a gyermeket körülvevő felnőttek viselkedése segítheti vagy akadályozhatja a reziliencia megjelenését a gyermekben (Hodge, 2009).

A témakörben végzett vizsgálatok azt is igazolták, hogy az egyén szerencsétlen körülményei nem vezetnek szükségszerüen rossz alkalmazkodáshoz. A jelenlegi reziliencia-kutatások kiemelik, hogy szükség lenne a stigmatizáló, patológiaközpontú fogalomhasználat lecserélésére. A reziliencia modelljeinek alkalmazása lehetővé teszi, hogy a nehézségekkel szembenéző gyermekeket és fiatalokat alaposabban megértsük és kiegyensúlyozottabban, gazdagabban tudjuk megsegíteni. A fiatalok szembenézhetnek a kihívásokkal és az esélyek ellenére elboldogulhatnak. A siker egyik legfontosabb faktora a jelentős kapcsolat egy vagy több gondoskodó felnőttel (Laursen és Birmingham, 2003). Ebből a perspektívából szemlélve a reziliencia pedagógiai relevanciája különösen nyilvánvalóvá válik, hiszen ezeket a kulcskapcsolatokat jó eséllyel a pedagógusok is jelenthetik.

\section{A fejlödési rizikó meghatározása}

A rezilienciával elválaszthatatlanul összefüggenek a fejlődést veszélyeztető rizikófaktorok és az ezek hatását ellensúlyozó, illetve az optimális fejlődési folyamatot támogató védőfaktorok. Werner és Smith (1992) definíciója szerint a rizikótényezők olyan pszichológiai vagy környezeti változók, melyek növelik a rosszul alkalmazkodás viselkedési megnyilvánulásainak vagy az iskolai kudarcoknak a valószínú- 
ségét. A rizikófaktorok környezeti, biológiai, pszichológiai vagy kognitív feltételekre utalnak, amelyek akadályozhatják a gyermek optimális fejlődését és nagyobb fokú sérülékenységre hajlamosítanak (Werner és Smith, 1992, Benard, 2006, Rutter, 1987). Rutter (1987) szerint ezek a faktorok közvetlenül patológiás elváltozásokhoz és rossz fokú alkalmazkodáshoz vezetnek. A rizikófaktorok a környezet különböző formáiból eredhetnek, így az otthon, az iskola vagy a közösségek egyaránt forrásai lehetnek. Eredhetnek a gyermek hiedelmeiből vagy cselekvéseiből is. Blum (2002) úgy véli, a rizikó annak a mérőszáma, hogy egy személy mennyi stresszel találkozik életében, a reziliencia pedig azt írja le, hogy sikeresen vagy sikertelenül küzd meg vele. Definíciószerüen egy rizikófaktor olyan változó, amely bejósolja a korai iskolai kudarcokat, illetve bizonyos esetekben kapcsolatba hozhatók tanulási, érzelmi vagy szociális nehézségek kialakulásával és fennmaradásával (Huffmann, Mehlinger és Kerivan, 2000).

A sérülékenységet (vulnerabilitást) a reziliencia ellentéteként határozhatjuk meg. Ha egy gyermek különösen fogékony a hátrányos életkörülményekre, könynyen alakulnak ki nála pszichés zavarok, betegségek vagy viselkedési problémák, akkor a gyermek sérülékenységéről beszélhetünk. Az egészséges fejlődés ezekben az esetekben különösen veszélyeztetett. A sérülékenység utal a gyerek hajlamára, hogy bizonyos fajta, egyénileg jellemző zavarokat fejlesszen ki magában, ha rizikótényezőknek van kitéve. A komplex szituációkra való rugalmas reagálás képessége beszükül, így az alkalmazkodási készsége is csökken. Sagy és Dotan (1999) úgy vélik, hogy a teljes populáció sérülékeny bizonyos mértékủ stresszteli szituációk hatására.

A rizikó legegyszerübben külső (tehát a környezetből származó) és belső (az egyénen belüli) kategóriákba sorolható. A külső rizikótényezőket szokás több alcsoportra bontani, így a szükebb család, az iskola és a tágabb környezet vagy a társadalmi szinten megjelenő veszélyeztető tényezőkről beszélnek a kutatók.

Alapvető, hogy különbséget tegyünk a rizikó jelzései és müködési mechanizmusa között. Például hosszú éveken át mentális zavarok kialakulásában komoly rizikófaktornak tekintették a családtól való elválást vagy a szülő elvesztését. Kutatási eredmények igazolták, hogy nem elsősorban maga a veszteség vagy szeparáció az, ami a patológiai rizikót hordozza. Gyerekeknél és felnőtteknél is azt találták, hogy a fö rizikó a megzavart kapcsolatokból és a gyenge minőségü szülői gondoskodásból ered, amelyeket a szeparáció vagy veszteség előidézett. Ha a szeparáció vagy veszteség nem jár együtt megzavart kapcsolatokkal és rossz szülői gondoskodással, akkor csak csekély mértékben növeli a kockázatot. Viszont a kapcsolati zavarok és a rossz szülői gondoskodás szeparáció és veszteség nélkül is magukban hordozzák a pszichopatológia rizikóját. A viselkedésgenetikai kutatásokban hasonló eredményeket kaptak. A kockázatok ránézésre gyakran környezeti hatásokként értelmezhetőek, ugyanakkor olyan rizikókat is magukba foglalhatnak, amelyek nagymértékben genetikailag közvetítettek, például a család szétesése vagy a szülői gondoskodás 
nem megfelelő volta nyilvánvalóan kedvezőtlen környezetet jelent, de olyan szülői minőségekből is eredhetnek, amelyek részben genetikailag is meghatározottak (Rutter, 2000b; Sagy és Dotan, 1999; Masten, 2001).

A rizikó- és védőfaktorokkal kapcsolatosan megkerülhetetlen Emmy Werner (2000) híres hawaii longitudinális vizsgálata, amelyben az egyik szigeten az összes 1955-ben született gyermeket nyomon követték egészen 40 éves korukig. E követés célja az volt, hogy láthatóvá váljék a munka világába való illeszkedésük, a házassággal és a szülővé válással kapcsolatos tapasztalataik, valamint a stresszt kiváltó eseményekkel való megküzdés a rendelkezésre álló erőforrások felhasználásával.

A 837 fős kohorsz minden harmadik tagja közepes vagy súlyos fokú perinatális stresszt élt át, krónikus szegénységben nevelkedett, olyan szülökkel, akik semmilyen vagy csak minimális formális oktatásban vettek részt. Werner és munkatársai eleve elkülönítettek egy rizikós almintát, ami a minta harmadát tette ki, s az ebbe tartozó egyéneknél a kockázat már a születéskor jelen volt, a terhességgel kapcsolatos problémák, a szegénység vagy a házassági viszályok formájában. Ennek ellenére ezen alcsoport harmadából kompetens, magabiztos és gondoskodó fiatal felnőtt lett, noha többszörös rizikónak voltak kitéve (Werner, 2000).

A rizikósnak tekintett csoport kétharmada mutatott 18 évesen problémákat az életvezetés terén, tizenévesen teherbe estek, gondjaik akadtak a rendőrséggel, segítségre szorultak. A rizikós csoport egyharmada - amint fent jeleztük - azonban kompetens és gondoskodó fiatal felnőtté vált. Kevesebb problémát mutattak a kétharmadhoz képest, a szüleik szerint aktívak, érzelmesek és válaszkészek voltak. Werner és Smith (1992) szerint nekik már gyerekként voltak bizonyos önsegítö képességeik, jó szenzomotoros koordinációval és nyelvi készségekkel bírtak. Tizenéves korukban a problémamegoldás, a motorikus és kommunikációs készségek tovább fejlődtek, a felnőttkor küszöbére érve megfelelö önértékeléssel és teljesítményorientációval bírtak. Wernert az érdekelte, mi volt az, ami jóra fordította a rizikós egyharmad életét, olyannyira, hogy sokan közülük még a nem rizikós csoport tagjainál is jobban teljesítettek (Werner, 2000; Cox, 2004)

A kutatás során kiderült, hogy a házasságot nem kötött anya, az apa huzamosabb idejü távolléte, a hat és tíz éves kor közötti iskolaváltás vagy iskolaváltások, valamint az iskolai bukás erőteljes előrejelző szerepet töltöttek be férfiaknál a felnőttkorra nézve. Nőknél a felnőttkori megküzdés nehézségeit leginkább a tinédzserkori terhesség, a család financiális nehézségei, a kortársakkal való rossz kapcsolat jelezték előre (Werner, 2000).

A rizikófaktorok kölcsönhatásai növelik a kedvezőtlen kimenet valószínűségét. A kockázati tényezők legtöbbször nem önmagukban fordulnak elö, a gyermekek egyidejüleg általában több ilyen tényező hatásának vannak kitéve. Egy rizikófaktor önmagában nem növeli meg a negatív kimenet valószínüségét az alacsony rizikójú vagy rizikómenetes mintával összehasonlítva. A rizikófaktorok száma és a rizikónak kitettség időtartama fontosabb a kimenet megértése és bejóslása szem- 
pontjából, mint az egyszeri súlyos rizikó. Az egyidejüleg jelen levő rizikófaktorok számának növekedésével a negatív kimenetel esélye tehát nő, méghozzá sokkal nagyobb mértékben, mintha a különböző veszélyeztető hatásokat egyszerüen összegeznénk. Nagyobb számú rizikófaktor megléte több védöfaktor jelenlétét igényli annak érdekében, hogy a személyt megóvják a negatív kimenetelektől (Fallon, 2010). A rizikófaktorok számának növekedése nem csak a kedvezőtlen kimenet fokozott valószínüségét vetíti elö, hanem az érintett személynél megjelenő kompetenciák alacsonyabb szintjét is (Masten, 2001; Rutter, 2000a és b; Beardslee és Gladstone, 2001; Ceglédi, 2012; Fallon, 2010).

A rizikófaktorok lehetnek diszkrétek (időben elkülönülten jelennek meg, például egy kritikus életesemény) vagy folyamatosak (mint a krónikus szegénység), illetve proximális hatásúak (a gyermeket közvetlenül érintőek, mint például a szülők közötti konfliktus) és a disztális rizikótényezők (például: alacsony szocioökonómiai státusz). Az utóbbiak nincsenek közvetlen hatással a gyerekre, hanem mediátorként hatnak (Rutter, 2000b). Masten és Powell (2003) azt tapasztalták, hogy a rizikófaktorok tipikusan együtt jelennek meg, általában stresszteli tapasztalatok egész folyamatát indukálva és gyakran felhalmozódnak a gyerekek életében. Rutter (2000a) azt találta, hogy viszonylag ritkán vezetnek a genetikus faktorok önmagukban rossz kimenetekhez, ezek esetében általában többszörös, egymással összefüggő genetikai és környezeti kockázattal kell számolni.

Azoknál a személyeknél, akik a rosszul alkalmazkodó mintába tartoznak, különösen nagymértékü növekedés figyelhető meg az életkor elörehaladtával a függő események (tehát a személy saját viselkedéséhez kapcsolódó problémák) tekintetében. Ez arra utal, hogy a rosszul alkalmazkodók kompetens társaikhoz képest nagyobb mértékben járulnak hozzá saját nehézségeikhez (Masten és Powell, 2003). Az aktív sérülékenység szerepet játszik a rizikó értelmezésében, ti. ezek a személyek önmaguk konstruálják a stressz teli eseményeket, ahelyett, hogy pusztán reagálnának rájuk.

Masten (2001) hozzáteszi, hogy a rizikófaktorok számának vagy súlyosságának növekedésével a kimenetek rendszerint rosszabbodnak, hiszen például katasztrófahelyzetben egy gyerektől sem várjuk el, hogy reziliens legyen, amíg a fejlődéshez szükséges normális és biztonságos környezete helyre nem áll. Ilyen esetekben a reziliencia a trauma befejeződése utáni jó szintü felépülésre vonatkozik. Lehetséges, hogy egy gyerek reziliens és mégis szenved a trauma utóhatásaitól. A reziliencia nem jelent sérthetetlenséget (Masten, 2001).

További fontos megfigyelés, hogy a különböző rizikótényezőknek etnikai vonatkozásai is vannak. Homel, Lincoln és Herd (1999) megjegyzik, hogy a kisebbségi etnikai csoporthoz tartozó személyeknél a rizikó- és védőfaktorok természete, jelentése és hatása teljesen eltérö lehet a többségi etnikai csoport tagjaihoz képest. Ez a kérdés a magyarországi kontextusban is érvényes lehet. 


\section{A fejlődést veszélyeztető kockázatok}

A következőkben röviden bemutatom mindazokat a rizikófaktorokat, amelyek leggyakrabban előfordulnak, illetve a legkedvezőtlenebb hatást gyakorolhatják a gyermekek fejlődésmenetére. Bizonyos típusú kockázatok természetesen a földrajzi vagy a kulturális közegtől függetlenül, univerzálisan jelen lehetnek, míg mások csak specifikus kontextusokban fordulnak elö. A rizikófaktorok között vannak olyanok, melyek más faktorokhoz képest jelentősebb hatásúak, azonban fontos tudni, hogy az egyes kockázatok hatása kizárólag az egyén élettörténetén keresztül értelmezhetö, mérhető le.

Az egyénen belüli rizikófaktorokat egészségügyi-biológiai tényezőkre, személyiségvonásokra, képességekre, valamint viselkedéses jegyekre tagoltam.

Az egészségügyi-biológiai faktorok közül leggyakoribbak a problémás terhesség, az éretlenül, kis súllyal született gyermek, az idegrendszeri fejlödés megkésettsége vagy szabálytalansága, súlyos betegség kisgyermekként és a pszichofiziológiai jellemzők, például a pszichomotorikus vagy a nyelvi fejlettség problémái (Verlinden, Hersen és Thomas, 2000; Huffmann és mtsai, 2000; Masten és Powell, 2003; Cox, 2004; Blum, 2002).

A személyiségvonások közül említést érdemelnek a következők: nehéz temperamentum, külső kontrollosság, alacsony szintü önértékelés, alacsony szintü énhatékonyság, az önszabályozás alacsony szintü fejlettsége, a devianciát favorizáló hitek vagy attitüdök, illetve a remény hiánya (Verlinden és mtsai, 2000; Huffmann és mtsai, 2000; Beardslee és Gladstone, 2001; Blum, 2002).

A képességek tekintetében a legfontosabb rizikót a rossz általános kognitív képességek, az alacsony IQ és a kommunikáció nehézségei jelentik (Rahman, 1999; Huffmann és mtsai, 2000; Blum, 2002).

A gyermeki viselkedéses jegyek közül, amelyek kockázatot jelentenek, kiemelkednek a következők: korai viselkedési és beilleszkedési problémák, korai bevonódás antiszociális viselkedésbe, deviáns viselkedés gyermekkorban, iskolából való kimaradás, szerhasználat, tizenéves terhesség, agresszív előtörténet, önkárosító magatartásformák, hiperaktivitás, figyelemzavar, impulzivitás kisgyermekként. A nem hatása is megfigyelhető, például lányok gyakrabban válnak szexuális abúzus áldozatává és ennek következtében gyakrabban mutatnak klinikai szintet elérő szexuális problémákat (Huffmann és mtsai, 2000; Benard, 2006; Solt, 2012; Verlinden és mtsai, 2000; Burt, 2002, Blum, 2002; Christie, Harley, Nelson és Jones, é. n.).

A családi rizikótényezők között is többféle kategória figyelhetö meg. Ebben az összefüggésben a családon belüli kapcsolatok, a család státusza, a család müködése jelentik a további differenciálás alapját a rizikófaktorok bemutatásában.

A családon belüli kapcsolatok, amelyek leginkább veszélyeztethetik az optimális fejlődést: a nem megfelelő kötődés kialakulása a szülő és a gyermek között, az ellenségesség a szülö-gyerek kapcsolatban, a negatív anyai attitüdök, az apa hi- 
ánya vagy távolléte vagy alacsony bevonódása, a válás, új házasság, mostohaszülő, az anyától való szeparáció vagy gondozásba vétel (Verlinden és mtsai, 2000; Grotberg, 2003; Beardslee és Gladstone, 2001; Masten, 2001; Blum, 2002; Solt, 2012; Masten és Powell, 2003; Cox, 2004; Blum, 2002).

A családi státusz legtipikusabb rizikófaktorai: a krónikus szegénység, az alacsony szocioökonómiai státusz, az anya alacsony iskolai végzettsége, kisebbségi státusz, túlzsúfoltság, túl nagy családméret, nagyon fiatal szülő, munkanélküliség, antiszociális szülöi magatartás, gyakori költözés és a hajléktalanság (Masten és Powell, 2003; Rahman, 1999; Huffmann és mtsai, 2000; Cox, 2004; Jenkins és Keating, 1998; Grotberg, 2003; Verlinden és mtsai, 2000; Burt, 2002).

A család müködésében a legjellemzőbb fejlődést veszélyeztető tényezők: a súlyos házassági konfliktusok, fizikai, érzelmi vagy szexuális bántalmazás, elhanyagolás, instabil és alacsony kohéziójú család, anya depressziója vagy pszichiátriai megbetegedése, családtag halála, betegsége, fogyatékossága, a háztartás vezetőjének tapasztalatlansága vagy ügyetlensége, nem megfelelö, hatékony vagy rossz szülöi gyakorlatok, technikák, szerhasználó vagy kriminális szülö (Verlinden és mtsai, 2000; Jenkins és Keating, 1998; Masten és Powell, 2003; Solt, 2012; Grotberg, 2003; Cox, 2004; Benard, 2006; Christie, Harley, Nelson és Jones, é. n.; Burt, 2002; Blum, 2002).

Az oktatással-neveléssel és a kortársakkal kapcsolatos problémák meglehetösen széles kategóriát alkotnak, amelyet az oktatási intézmények, illetve az intézményes nevelés faktoraira, valamint a kortársakkal kapcsolatos tényezőkre osztottam.

Az oktatási intézmények veszélyeztető tényezői közül kiemelkednek a következők: a túlzsúfoltság, rossz infrastruktúra, magas tanuló/tanár arány, a tanárok kevésbé hozzáférhetőek, nem jó kapcsolat osztálytanítóval, óvodapedagógussal, alacsony szintü interakciók, alacsony szintủ elvárások, gyenge és inkonzisztens felnőtt irányítás, az összetartozás érzésének hiánya, nem releváns tanterv vagy tanórák, alacsony átlagos tanulmányi teljesítmény, az összetartozás érzésének hiánya, kevés lehetőség az egyéni különbségek megnyilvánulására (Christie és mtsai, é. n.; Huffmann és mtsai, 2000; Reed-Victor, 2003; Cox, 2004; Verlinden és mtsai, 2000; Solt, 2012).

Egyéb, intézményes neveléssel kapcsolatos tényezők közül jelentősek: a fiatal életkorban nagy arányú nem anyai gondoskodás, például bölcsőde, aszociális elszigetelődés az intézményen vagy a kortárscsoporton belül és az oktatási-nevelési intézmény elfordulása a problémás gyermektől, például eltanácsolás, támogatás hiánya (Solt, 2012; Huffmann és mtsai, 2000; Verlinden és mtsai, 2000).

A kortársakkal kapcsolatos vonatkozások, amelyek gátjai lehetnek az ideális fejlődésnek: kapcsolati problémák a kortársakkal, kiközösítés, gúnyolódás, elutasítás az osztálytársak részéről, bullying és az antiszociális kortárscsoport, bandákhoz csapódás (Huffmann és mtsai, 2000; Verlinden és mtsai, 2000; Christie és mtsai, é. n.; Solt, 2012). 
Az egyénen, családon, intézményes nevelésen és kortárscsoporton túlmutató rizikótényezőket a tágabb közösség, illetve a társadalom kockázatai jelentik.

A tágabb közösség rizikótényezői a lakókörnyezetben tapasztalható nagyarányú kriminalitás, droghasználat, bandatevékenység, a nem megfelelő, nem biztonságos, nem rendezett lakókörnyezet, illetve az alacsony felnött kontroll (Engle, Castle és Menon, 1996; Verlinden és mtsai, 2000; Reed-Victor, 2003; Christie és mtsai, é. n.).

A társadalmi szintü kockázatok közül hangsúlyosak következők: a szegénység, az alacsony szocioökonómiai státusz, a limitált közgazdasági erőforrások, a magas mobilitási arány, a bármilyen jellegű erőszak, a szociális támogatás hiánya, az instabil kormányzat, a politikai elnyomás, a természeti katasztrófák, a kultúra és a nemi szerepek elvárásai és az elöítéletek (Verlinden és mtsai, 2000; Huffmann és mtsai, 2000; Reed-Victor, 2003; Christie és mtsai, é. n.; Masten és Powell, 2003; Rahman, 1999; Engle és mtsai, 1996; Grotberg, 2003; Homel és mtsai, 1999; Mykota és Muhajarine, 2005; Blum, 2002).

Mykota és Muhajarine (2005) hangsúlyozzák, hogy a szegénység, a munkanélküliség és az alacsony általános képzettségi szint a hátrányos helyzetü területeken kumulatív módon hat és az egyébként is szükös erőforrások tekintetében az átlagosnál nagyobb igényeket támaszt. Ez negatívan befolyásolja az erőforrások odavonzását és megtartását (például szervezetek, intézmények, szolgáltatások), az iskolák pedig magukra maradnak, mivel kevés partnerintézménnyel tudnak együttmüködni a helyzet javítása érdekében.

\section{A rizikó hatása, a pedagógia lehetőségei}

A rizikótényezők elemzésével összefüggésben Danis és Szilvási (2011) az életben való boldogulást és optimális fejlődést taglalják, ami szorosan kapcsolódik a reziliencia kérdésköréhez. Megítélésük szerint a családi környezet szociális-gazdaságidemográfiai helyzetét leginkább rizikóindex használatával lehet jellemezni. A rizikóindex több szempont egyidejü figyelembevételére és mérésére épül (Danis, Szilvási, 2011). Jenkins és Keating (1998) voltak az elsők, akik rizikóindexet állítottak össze kutatásukban. Azt találták, hogy azok a gyerekek, akik nem voltak veszélyeztető hatásoknak kitéve, 10 százalékban mutattak kedvezőtlen kimenetet (adott esetben magatartási problémákat), hasonlóan azokhoz, akik egy rizikótényező hatását szenvedték el. Akik négy vagy annál is több veszélyeztető faktornak voltak kitéve, 50 százalékban mutattak magatartási problémákat. A kockázat tehát kumulatívnak bizonyult.

Ezzel együtt fontos azt is megemlíteni, hogy Masten (2001) megítélése szerint a reziliencia története nem pusztán a kevesebb rizikófaktorról szól. Olyan gyerek is teljesíthet jól, akinél öt-hat rizikófaktor is jelen van. Masten szerint szükséges felmérni a gyerek, a család vagy a közösség azon jellemzőit, melyek szerepet játszanak a kimenetek nagy varianciájában. Ezzel szemben Engle és munkatársai (1996) 
úgy vélik, hogy a rizikó folyamatjellegéből fakadóan a rizikófaktorok össz-száma és a nekik való kitettség ideje fontosabb, mint az egyszeri súlyos trauma vagy nehézség. A reziliencia és a hozzá kapcsolódó rizikófaktorok alaposabb megértése segítséget nyújthat a pedagógiai gyakorlatban a gyermekek, tanulók alaposabb megismeréséhez, helyzetük árnyaltabb elemzéséhez, valamint arra is lehetőséget biztosít, hogy a kedvezötlen helyzetben levő vagy a fejlődésükben fenyegetett gyermekek számára olyan utakat és lehetóségeket nyissanak meg a pedagógusok, amelyek képesek lehetnek ellensúlyozni az őket ért negatív hatásokat és fejlődésüket optimális mederben tartani vagy oda visszaterelni.

A rezilienciát, mint fejleszthető területet, elérhető pedagógiai célt határozhatjuk meg, erre vonatkozóan igen nagymértékủ a témával foglalkozó kutatók közötti egyetértés (Fallon, 2010; Masten, 2001; Engle és mtsai, 1996; Stoiber és Gettinger, 2011). Különös jelentöséggel bír a reziliencia fejlesztésében az iskolai közeg, amely számos fejlődési lehetőséget, stabil, meleg és ösztönző kapcsolatokat, pozitív szerepmodelleket, az odatartozás érzését, a részvétel lehetőségét kínálja fel. Az iskola, mint a reziliencia fejlesztésének kiemelt terepe (Toland és Carrigan, 2011) különösen a rizikónak kitett, hátrányosabb helyzetű, kevésbé megfelelő családi háttérből érkező gyermekek esetén jelent védőfaktort.

Az iskolai közegben olyan pozitív kapcsolatokat élhetnek át a gyermekek, amelyek pozitív szerepmodelleket, illetve támogató, ösztönző és fejlődési lehetőségeket biztosító faktorokként értelmezhetünk. A pedagógusok rezilienciát fejlesztö tevékenysége önmagukra, saját pszichés jóllétükre is visszahat (Howard és Johnson, 2004). A tanárok felkészítésének a reziliencia fejlesztésére nem szükséges konkrét programokra fókuszálni, sokkal inkább a kapcsolatok mélyebb szintjére, az elvárások megváltoztatására. A tanárok belső képessége, amely lehetővé teszi a reziliencia megjelenését, a tanulókat is mozgósíthatja. A tanároknak szükséges nagyobb türelmet gyakorolni, valamelyest engedni a szoros ellenőrzésből. A tanárok a reziliencia fejlesztése során nem kizárólag az egészséges fejlődéshez és a sikeres tanuláshoz járulnak hozzá, hanem a XXI. században kritikus készséggé váló kreatív polgárság kialakításához (Benard, 2006). A tanárképzés során a pedagógusokban rejlő reziliencia kibontakoztatása hozzájárul a reziliencia sikeres fejlesztéséhez a tanulóknál a későbbiekben.

\section{Irodalom}

Alvord, M. K. - Gurwitch, R. - Palomares, R. S. (2003): A Guide for Parents and Teachers. American Psychological Association. URL: www.apahelpcenter.org/dl/resilience_ guide-for_parents_and_teachers.pdf Letöltés ideje: 2008. december 3.

Beardslee, W. R. - Gladstone, T. R. G. (2001): Prevention of Childhood Depression: Recent Findings and Future Prospects. Biological Psychiatry, 12. sz. 1101-1110.

Békés Vera (2002): A reziliencia-jelenség, avagy az ökologizálódó tudományok tanulságai egy ökologizált episztemiológia számára. In: Forrai Gábor - Margitay Tihamér (szerk.): 
Tudomány és történet - Tanulmánykötet Fehér Márta tiszteletére. Typotex, Budapest, 215-228.

Benard, B. (2006): Using Strengths-Based Practice to Tap the Resilience of Families. In: Saleebey, D. (szerk.): Strengths Perspective in Social Work Practice, 4/e, Allyn \& Bacon, Boston, 197-220.

Blaustein, M. E. - Kinniburgh, K. M. (2010): Treating Traumatic Stress in Children and Adolescents, How to Foster Resilience through Attachment, Self-Regulation, and Competency. The Guilford Press, New York, London.

Blum, R. W. (2002): Risk and Resilience: A Model for Public Health Interventions for Adolescents. University of Minnesota, Division of General Pediatrics \& Adolescent Health, Minneapolis.

Burt, M. R. (2002): Reasons to Invest in Adolescents. Journal of Adolescent Health, 6. sz. $136-152$.

Ceglédi Tímea (2012): Reziliens életutak, avagy a hátrányok ellenére sikeresen kibontakozó iskolai karrier. Szociológiai Szemle, 2. sz. 85-110.

Christie, C. A. - Harley, D. A. - Nelson, C. M. - Jones, K. (é. n.): Promoting Resilience in Children: What Parents Can Do. URL: cecp.air.org/familybriefs/docs/Resiliencyl.pdf Letöltés ideje: 2014. január 9.

Cox, D. A. (2004): Leaders Fostering Resiliency in Schools, University of Pittsburgh, doktori disszertáció. URL: http://d-scholarship.pitt.edu/10354/1/COXDEBORAHA20004.pdf Letöltés ideje: 2012. március 28.

Danis Ildikó - Szilvási Léna (2011): „Iskola, iskola, ki a csoda jár oda?” II., A sikeres iskolakezdés háttere - társadalmi, intézményi és családi tényezők. Kézirat, Bright Future, Göd.

Engle, P. L. - Castle, S. - Menon, P. (1996): Child Development: Vulnerability and Resilience. Social Science \& Medicine, 5. sz. 621-635.

Fallon, C. M. (2010): School Factors that Promote Academic Resilience in Urban Latino High School Students. UMI Dissertation Publishing, ProQuest LLC., Ann Arbor, URL: http://ecommons.luc.edu/cgi/viewcontent.cgi?article=1121\&context=luc_diss Letöltés ideje: 2014. január 9.

Goldstein, S. - Brooks, R. B. (szerk. 2013): Handbook of Resilience in Children, Second Edition. Springer, New York.

Grotberg, E. H. (2003): Resilience for Today: Gaining Strength from Adversity. Praeger, Westport, Connecticut, London.

Homel, R. - Lincoln, R. - Herd, B. (1999): Risk and Resilience: Crime and Violence Prevention in Aboriginal Communities. The Australian and New Zealand Journal of Criminology, 2. sz. URL: http://epublications.bond.edu.au/cgi/viewcontent.cgi?article $=1087 \&$ context $=$ hss_pubs Letöltés ideje: 2015 . március 3 .

Hodge, J. W. (2009): Let Our Youth Speak: A Phenomenological Analysis of Resilience in Students with Multiple Risk Factors. Virginia Politechnic Institute and State University, doktori disszertáció. URL: http://scholar.lib.vt.edu/theses/available/etd-04142009 -075106/unrestricted/FINALDISSERTATION.pdf Letöltés ideje: 2013. október 4. 
Howard, S. - Johnson, B. (2004): Resilient Teachers: Resisting Stress and Burnout. School Psychology of Education, 7. sz. 399-420.

Huffmann, L. C. - Mehlinger, S. L. - Kerivan, A. S. (2000): Risk Factors for Academic and Behavioral Problems at the Beginning of School. Paper 1, CE-CREDIT.com, „Your Continuing Education Resource”, URL: http://secure.ce4alliance.com/articles/ 9580/riskfactorsacademic.pdf Letöltés ideje: 2015. március 2.

Jenkins, J. - Keating, D. (1998): Risk and Resilience in Six- and Ten-Year-Old Children. Applied Research Branch Strategic Policy, Human Resources Development Canada

Laursen, E. K. - Birmingham, S. M. (2003): Caring Relationships as a Protective Factor for At-Risk Youth: An Ethnographic Study. Families in Society: The Journal of Contemporary Human Services, 2. sz. 240-246.

Masten, A. S. (2001): Ordinary Magic: Resilience Processes in Development. American Psychologist, 3. sz. 227-238.

Masten, A. S. - Powell, J. L. (2003): A Resilience Framework for Research, Policy, and Practice. In: Luthar, S. S. (szerk.): Resilience and Vulnerability: Adaptation in the Context of Childhood Adversities, New York, Cambridge University Press, 1-26.

Masten, A. S. and J. Obradovic. 2007. Disaster preparation and recovery: lessons from research on resilience in human development. Ecology and Society 13(1): 9. [online] URL: http://www.ecologyandsociety.org/vol13/iss1/art9/

Merrell, K. W. - Levitt, V. H. - Gueldner, B. A. (2010): Proactive Strategies for Promoting Social Competence and Resilience. In: Peacock, G. G. - Ervin, R. A. - Daly III, E. J. Merrell, K. W. (Ed.): Practical Handbook of School Psychology. Effective Practices for the $21^{\text {st }}$ Century. The Guilford Press, New York, London, 254-273.

Mykota, D. B. - Muhajarine, N. (2005): Community Resilience Impact on Child and Youth Outcomes: A Neighborhood Case Study. Canadian Journal of School Psychology, 20: 5-20.

Padron, Y. N. - Waxman, H. C. - Huang, S. L. (1999): Classroom Behavior and Learning Environment Differences between Resilient and Nonresilient Elementary School Students. Journal of Education for Student Placed at Risk 1. sz. 63-81.

Rahman, A. Y. (1999): Early Intervention or Resilience, A Case Study. AUSEINET Nemzetközi konferencia, Adelaide, 1999. június 6-8.

Reed-Victor, E. (2003): Supporting Resilience of Children and Youth. Project HOPE Information Brief No. 1, Virginia Department of Education, Williamsburg VA.

Rutter, M. (1987): Psychosocial Resilience and Protective Mechanisms. American Journal of Ortopsychiatry, 57, 316-331.

Rutter, M. (2000a): Children in Substitute Care: Some Conceptual Considerations and Research Implications. Children and Youth Services Review, 9-10. sz. 685-703.

Rutter, M. (2000b): Resilience in the Face of Adversity. Medicine Meets Millenium, World Congress on Medicine and Health, 2000. július 21 - augusztus 31.

Sagy, S. - Dotan, N. (2001): Coping Resources of Maltreated Children in the Family: A Salutogenic Approach. Child Abuse \& Neglect, 25, 1463-1480. 
Seiler, L. (2008): Cool Connections with Cognitive Behavior Therapy, Encouraging SelfEsteem, Resilience and Well-Being in Children and Young People Using CBT Approach. Jessica KIngsley Publishers, London and Philadelphia.

Shumov, L. - Vandell, D. - Posner, J. (1999): Risk and Resilience in the Urban Neighborhood: Predictors of Academic Performance aamong Low-Income Elementary School Children. Merrill-Palmer Quarterly, 45: 309-331.

Solt Ágnes (2012): Peremen billegö fiatalok. Veszélyeztető és kriminalizáló tényezők gyermek- és ifjúkorban. Doktori (PhD) disszertáció, kézirat, Budapest. URL: http://www.okri. hu/images/stories/kutatok/soltagnes/disszertacio.pdf Letöltés ideje: 2014. július 22.

Stoiber, K. C. - Gettinger, M. (2011): Functional Assessment and Positive Support Strategies for Promoting Resilience: Effects on Teachers and High-Risk Children. Psychology in Schools, 7. sz. 686-706.

Szakács Katalin (2007): A nevelési tanácsadók helyzete és szerepe a tanulási és más zavarok megoldásában. Nevelési Tanácsadók Egyesülete, Oktatási kerekasztal. URL: http:// www.oktatasikerekasztal.hu/hattertanulmanyok/06/szakacs_nevelesi_tanacsadok.pdf Letöltés ideje: 2015. június 1.

Toland, J. - Carrigan, D. (2011): Educational Psychology and Resilience: New Concept, New Opportunities, School Psychology International, 1. sz. 95-106.

Ungar, M. - Liebenberg, L. - Boothroyd, R. - Kwong, W. M. - Lee, T. Y. - Leblanc, J. - Duque, L. - Maknach, A. (2008): The Study of Youth Resilience across Cultures: Lessons from a Pilot Study of Measurement Development. Research in Human Development, 3. sz. 166-180.

Verlinden, S. - Hersen, M. - Thomas, J. (2000): Risk Factors in School Shootings. Clinical Psychology Review, 1. sz. 3-56.

Werner, E. E. (2000): Protective Factors and Individual Resilience. In: Skonkoff, J. P. - Meisels, S. J. (szerk.): Handbook of Early Childhood Intervention 2. kiadás, Cambridge University Press, 115-132.

Werner, E. E. - Smith, R. S. (1992): Overcoming the Odds: High Risk Children from Birth to Adulthood. Cornell University Press, New York. 